\title{
Lip Stick
}

\section{Elisabeth Mackenzie}

Le Rouge à lèvres évoque les contours de la féminité hétéronormative, l'accent étant mis sur le signifiant le plus puissant d'une telle identité : le rouge à lèvres rouge. Cet emblème particulier de la féminité conventionnelle, son habileté à dire des "mensonges » est cependant déstabilisé par son statut d'apparence et de performance.

these lips

both muted

told too fat

that colour's all wrong

like wearing red lipstick

inappropriately

in public

between your thighs

speaking for you

telling lies

where others find truths

they'd long suspected

while you

find peace

and lend it

to me

like a paintbrush

stained creation:

you know which part counts. 